\title{
PENINGKATAN KEMAMPUAN DAN PENDAPATAN PENGUSAHA KERUPUK IKAN HARUAN DI KELURAHAN KUIN UTARA KECAMATAN BANJARMASIN UTARA
}

\author{
Prihatini Ade Mayvita ${ }^{1}$, Firda Herlina ${ }^{2}$, Dwi Retno Sari ${ }^{3}$ \\ ${ }^{1}$ Fakultas Ekonomi, Universitas Islam Kalimantan \\ ${ }^{2}$ Fakultas Teknik, Universitas Islam Kalimantan \\ ${ }^{3}$ Fakultas Teknologi Informasi, Universitas Islam Kalimantan \\ Email : ademayvita@gmail.com
}

\begin{abstract}
South Kalimantan has great potential in the development of fisheries and marine sector in order to increase regional development and community welfare. Haruan (Cork) is one of the popular local fishes in South Kalimantan. Efforts to develop the processed fish Haruan (Gabus) itself, especially in South Kalimantan is still not optimal, the processed fish that Cork is mostly done is processing of salted fish Cork and crackers. In the city of Banjarmasin itself the most processed development of Gabus fish is the processing of crackers. Haruan fish cracker processing business has not been run optimally. Processing crackers in Banjarmasin there are many in the district of North Banjarmasin, especially in the village of North Kuin. The method used in this activity is through counseling / delivery of materials, discussion, implementation, evaluation, and mentoring. The objective of this activity is expected to increase income for Haruan fish cracker processing business through innovation and technology transfer with packaging improvement, production increase and establishment of cooperatives which will ultimately improve the prosperity for the community so that the economy and tourism sector of the region can be more developed. The result of this activity is the change of Haruan Rahmatul fish cracker and Haruan $\mathrm{Hj}$ fish cracker. Maspah previously used simple packaging without being pressed with special tools and with less attractive labels then after the counseling and providing the aid of press machines, plastic packaging and labels, became standard packaging so it can be sold in mini market and gift shop. The owner of Haruan Rahmatul and $\mathrm{Hj}$. Maspah also has recorded (bookkeeping) in their business activities. In the production process of cracker cutting that was previously manual after the help of a tool to make the cracker chip crackers in the process of cutting more efficient kerupuknya. In the case of the establishment of a cooperative for Haruan fish cracker business which is incorporated in Citra 2 group is still in process because it is still not sufficient to fund the principal savings.
\end{abstract}

Keywords: Haruan fish, chips, cooperation, innovation, technology

\section{PENDAHULUAN}

Ikan gabus atau ikan Haruan dalam bahasa Banjar merupakan salah satu ikan lokal yang sangat digemari di Kalimantan, khususnya di Kalimantan
Selatan, banyak kuliner di Kalimantan Selatan berbahan baku ikan Gabus, diantara yaitu Ketupat Kandangan, Masak Merah, dan Sayur Asam Banjar. Ikan Gabus merupakan ikan yang 
hidup di air kotor dengan kadar oksigen rendah, dengan bentuk yang buruk, namun memiliki rasa yang lezat tidak kalah dengan rasa ikan Salmon, dan mudah ditemukan di pasar-pasar tradisional apabila memasuki musimnya. Ikan Gabus sendiri memiliki manfaat yang sangat besar untuk kesehatan, kandungan albuminnya yang sangat tinggi yaitu $6,2 \mathrm{gr} / 100 \mathrm{cc}$ dapat membantu mempercepat proses penyembuhan berbagai macam penyakit diantaranya kekurangan gizi dan HIV/AIDS (Nurmaya Napitu, 2010) .

Selama ini produksi ikan Gabus hanya mengandalkan tangkapan dari alam terutama dari sungai dan rawa, sehingga dapat dikatakan produksi ikan Gabus tergantung dari musim atau ketersediaan di alam. Apabila memasuki musimnya maka produksinya akan melimpah sehingga harga jualnyapun akan murah, tetapi apabila tidak memasuki musimnya maka harga jual ikan Gabus akan mencapai Rp.100.000 per kilogram. Ikan Gabus belum bisa diproduksi secara massal seperti halnya ikan Nila, Patin, ikan Mas, karena belum bisa dipijahkan secara buatan (forum kerjasama Agribisnis, Produksi Ikan
Gabus

skala komersialwww.foragri.wordpress.com)

Di kota Banjarmasin pengembangan hasil olahan ikan Gabus yang paling banyak adalah pengolahan kerupuk. Pengrajin atau usaha menghasilkan olahan kerupuk Haruan tersebut masih berupa usaha rumah tangga atau usaha kecil menengah (UKM). Industri rumah tangga pengolahan kerupuk di Banjarmasin banyak terdapat di kecamatan Banjarmasin Utara khususnya di kelurahan Kuin Utara. Banjarmasin Utara sebagai salah satu kecamatan dari lima kecamatan yang ada di kota Banjarmasin mempunyai potensi industri kerakyatan yang dapat dikembangkan. Kecamatan Banjarmasin Utara terdiri dari 9 kelurahan, yaitu Kuin Utara, Pangeran, Sungai Miai, Antasan Kecil Timur, Surgi Mufti, Sungai Jingah, Alalak Utara, Alalak Selatan, Alalak Tengah, Sungai Andai.

Di kelurahan Kuin Utara sendiri ada 14 (empat belas) usaha pengolahan kerupuk. Usaha tersebut tergabung dalam 2 kelompok usaha, kelompok pertama dengan nama Citra 1 dan kelompok kedua dengan nama Citra 2. Usaha tersebut cukup menjanjikan karena dapat menghasilkan keuntungan 
yang cukup besar. Kerupuk Haruan dengan berat bersih 200 gram dijual dengan harga rata-rata Rp. 14.000,00 atau Rp.70.000,00 per kilogramnya. Produksi kerupuk ikan Haruan di kelurahan Kuin Utara sudah berjalan cukup lama. Kerupuk Haruan hasil produksi di kelurahan Kuin Utara memiliki keunggulan karena tidak mengandung bahan pengawet. Selain itu diolah dengan perbandingan bahan baku ikan Haruan dengan bahan lainnya 1 : 1, sehingga rasa ikan Haruannya lebih terasa. Kerupuk ikan Haruan dijadikan sebagai oleh-oleh khas Kalimantan Selatan yang cukup terkenal. Diharapkan dengan adanya Pemberdayaan potensi ekonomi lokal di wilayah Kuin Utara khususnya untuk usaha pengolahan kerupuk ikan Haruan dapat menjadi peluang untuk mewujudkan daerah yang mandiri dan maju berbasis ekonomi kreatif yang dapat memenuhi kebutuhan lokal maupun regional. Disamping sebagai pengembangan sektor industri rakyat juga dapat menjadi salah satu motor penggerak dalam upaya meningkatkan daya beli masyarakat melalui pemberdayaan ekonomi lokal.

\section{KHALAYAK SASARAN}

Khalayak sasaran dalam pengabdian ini adalah usaha kerupuk ikan Haruan Rahmatul dan usaha kerupuk Ikan Haruan Hj. Maspah yang tergabung dalam kelompok usaha kerupuk Citra 2.

\section{METODE PELAKSANAAN}

Metode kegiatan dalam pengabdian ini adalah penyampaian materi, diskusi dan pendampingan kepada usaha kerupuk ikan Haruan Rahmatul dan usaha kerupuk ikan $\mathrm{Hj}$. Maspah. Penyampaian materi terkait dengan manajemen usaha dan pembukuan sederhana. Sedangkan diskusi dan pendampingan terkait masalah mesin pemotong kerupuk dan pendirian koperasi.

\section{HASIL DAN PEMBAHASAN}

Sosialisasi Program berupa penjelasan program kepada mitra disertai kesediaan mitra 1 dan mitra 2 ditandai dengan telah ditandatangani kesediaan bekerjasama, namun karena kegiatan usaha juga melibatkan berbagai pihak diantaranya tenaga kerja dari pelaku usaha, maka sosialisasi perlu juga dilakukan terhadap mereka, karena pihak lain /selain pemilik usaha 
pengolahan kerupuk ikan Haruan juga akan turut terlibat dalam aktivitas pendampingan, serta secara langsung turut berperan untuk mencapai keberhasilan kegiatan.

Perbaikan usaha pengolahan kerupuk ikan Haruan disusun sebagai bagian dari proses pengembangan usaha. Rencana perbaikan usaha disusun sebagai arah pengembangan kegiatan usaha dan akan menjadi pedoman dalam monitoring dan evaluasi perkembangan usaha tersebut. Perbaikan usaha meliputi perbaikan manajemen usaha, perbaikan kemasan dan label, strategi pemasaran yang meliputi saluran distribusi.

Perbaikan manajemen usaha dilakukan dengan melakukan pelatihan pembukuan sederhana dan manajemen usaha. "Manajemen adalah fungsi untuk mencapai sesuatu memulai kegiatan orang lain dan mengawasi usaha-usaha individu untuk mencapai tujuan bersama (Manullang, 2003;45,d). Supaya tujuan usaha atau bisnis untuk mencapai keuntungan dapat tercapai dengan optimal maka diperlukan perbaikanperbaikan dalam mengelola usaha tersebut. Menurut Tjiptono $(2002 ; 6)$ strategi pemasaran adalah alat fundamental yang direncanakan untuk mencapai tujuan perusahan dengan mengembangkan keunggulan bersaing yang berkesinambungan melalui pasar yang dimasuki dan program pemasaran yang digunakan untuk melayani pasar sasaran tersebut. Dengan keunggulan bersaing yang dimiliki suatu usaha misalnya unggul dalam teknologi produksi maka suatu usaha dapat tetap bertahan atau berjalan secara secara berkesinambungan.

Selain itu pencatatan transaksi usaha penting dilakukan karena terkait dengan keberlangsungan suatu usaha dan melihat perkembangan keuntungan yang diperoleh. Pelatihan tersebut dilakukan agar adanya perbaikan dalam pencatatan transaksi usaha. Pelatihan tersebut diikuti oleh 10 pelaku usaha kerupuk Ikan Haruan yang tergabung dalam kelompok Citra 2.

Sedangkan untuk manajemen usaha meliputi perbaikan saluran distribusi dan kemasan serta label. Selama ini penjualan produk dilakukan hanya menunggu pembeli yang datang atau bersifat pasif. Sehingga untuk memperluas pemasaran produk maka diperluas saluran distribusi. Produk yang memiliki kemasan yang bagus, menarik dan sesuai dengan standar dapat menaikkan nilai jual produk 
tersebut, karena salah satu syarat produk yang dapat dijual di minimarket atau retail adalah kemasan yang memenuhi standar. Berdasarkan keadaan tersebut maka kami mengupayakan perubahan pada kemasan produk dan label Mitra 1 dan Mitra 2.

Strategi Pemasaran menurut Tjiptono (2002;6) merupakan alat fundamental yang direncanakan untuk mencapai tujuan perusahan dengan mengembangkan keunggulan bersaing yang berkesinambungan melalui pasar yang dimasuki dan program pemasaran yang digunakan untuk melayani pasar sasaran tersebut. Dengan keunggulan bersaing yang dimiliki suatu usaha misalnya unggul dalam teknologi produksi maka suatu usaha dapat tetap bertahan atau berjalan secara secara berkesinambungan.

Sedangkan saluran distribusi (Nitisemito, 1993;102) adalah lembagalembaga distributor atau lembagalembaga penyalur yang mempunyai kegiatan untuk menyalurkan atau menyampaikan barang-barang atau jasajasa dari produsen ke konsumen. Semakin diperluasnya atau diperbanyaknya saluran distribusi maka akan memperbanyak barang yang akan disalurkan ke konsumen. Kegiatan pemasaran yang yang dilakukan oleh Mitra 1 dan dan Mitra 2 selama ini hanya menunggu pembeli datang ke tempat produksi mereka atau bersifat pasif, dalam rangka meningkatkan atau memperbanyak produk yang akan disalurkan ke konsumen maka perlu diperluas saluran distribusi mereka. Berdasarkan kesiapan produk mereka yang telah memiliki label dan kemasan yang baru maka dengan kami membantu mereka untuk memperluas saluran distribusi dengan menitipkan produk mereka di minimarket dan toko oleh-oleh.

Hasil kegiatan ini adalah terjadinya perubahan pada kemasan kerupuk ikan Haruan Rahmatul dan kerupuk ikan Haruan $\mathrm{Hj}$. Maspah yang sebelumnya menggunakan kemasan sederhana tanpa dipress dengan alat khusus serta dengan label yang kurang menarik kemudian setelah dilakukan penyuluhan dan pemberian bantuan mesin press, plastik kemasan dan label, menjadi kemasan yang standar sehingga dapat dijual di minimarket dan toko oleh-oleh.

Pemilik usaha kerupuk ikan Haruan Rahmatul dan Hj. Maspah juga telah melakukan pencatatan (pembukuan) dalam kegiatan usaha 
mereka. Pada proses produksi yaitu pemotongan kerupuk yang sebelumnya bersifat manual setelah diberikan bantuan alat pemotong kerupuk menjadikan usaha kerupuk tersebut dalam proses pemotongan kerupuknya lebih efisien. Dalam hal pendirian koperasi bagi usaha kerupuk ikan Haruan yang tergabung dalam kelompok Citra 2 masih dalam proses karena masih belum mencukupi untuk dana simpanan pokok.

\section{FOTO KEGIATAN}

Gambar 1. Pelatihan Pembukuan Sederhana dan Manajemen Usaha

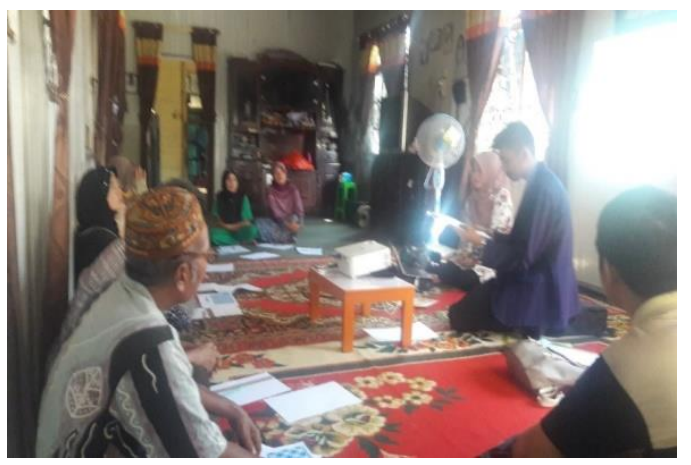

Gambar 2. Produk Mitra 1 dan Mitra 2

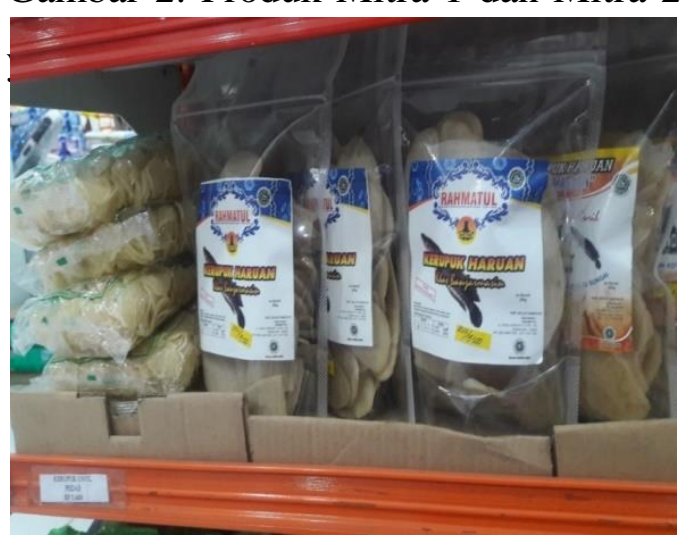

Gambar 3. Mitra 1 dan mitra 2 di depan alat pemotong kerupuk

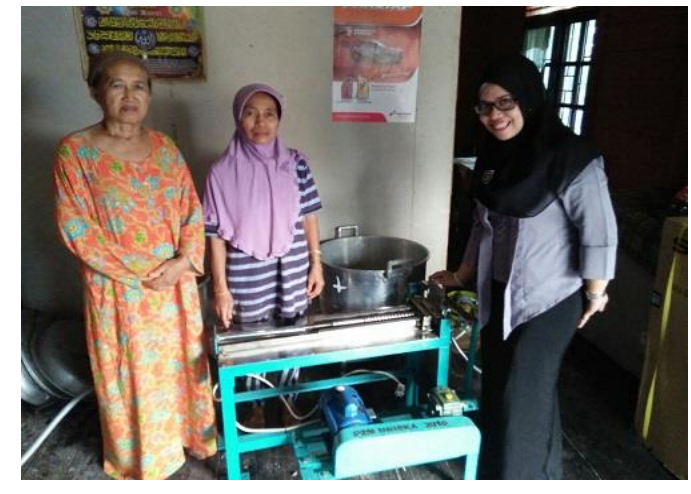

\section{KESIMPULAN}

Berdasarkan kegiatan yang telah kami lakukan dapat terlihat perubahan pada usaha kerupuk ikan Haruan Rahmatul dan $\mathrm{Hj}$. Maspah, diantaranya mereka mulai melakukan pencatatan pada setiap transaksi usaha mereka yang sebelumnya tidak mereka lakukan. Kemudian produk mereka dengan kemasan yang baru mulai dijual di minimarket dan toko oleh-oleh dimana sebelumnya hanya dijual di depan rumah mereka. Dalam proses produksi untuk memotong kerupuk mereka telah menggunakan mesin pemotong kerupuk, dengan menggunakan mesin tersebut proses produksi mereka dapat berjalan lebih efisien dan efektif. Untuk mendukung dalam hal permodalan bagi usaha kerupuk ikan yang tergabung dalam kelompok Citra 2 maka didirikan pra koperasi, karena masih terbentur 
dalam pengumpulan dana simpanan pokok. Sesuai dengan tujuan program kegiatan ini yaitu peningkatan kesejahteraan masyarakat, dengan kegiatan yang telah kami lakukan dapat terlihat perubahan dalam kegiatan usaha produksi kerupuk ikan Haruan (Gabus) yang pada akhirnya meningkatkan pendapatan mereka. Namun pada dasarnya kegiatan tersebut tidak dapat berhenti sampai disitu, kami menyarankan masih perlunya pendampingan dari pihak-pihak terkait seperti Dinas Koperasi dan Dinas Perdagangan terlepas dari pendampingan dari kami yang masih terus kami lakukan. Dengan pendampingan tersebut maka program bantuan yang diberikan akan dapat berjalan secara berkesinambungan yang pada akhirnya dapat meningkatkan kesejahteraan masyarakat khususnya di kelurahan Kuin Utara Kotamadya Banjarmasin.

\section{DAFTAR PUSTAKA}

Manullang, 2003. Dasar-dasar Manajemen, GajahMada University Press

Musmini, Lucy Sri., Andiani, Nyoman Dini., Erni Sulindawati, Ni Luh Gede., 2013. Pelatihan Penyusunan laporan Keuangan Berpedoman pada Akuntansi Perhotelan bagi Anggota Perhimpunan Hotel dan Restoran Indonesia (PHRI) di Kecamatan Buleleng, Jurnal Akuntansi Program Diploma III Fakultas Ekonomi dan Bisnis Universitas Pendidikan Ganesha

Nurmaya Napitu., 2010. Jurnal Pengabdian, vol 16 no 60

Nitisemito, Alex., 1993. Marketing, Ghalia Indonesia, Jakarta

Tjipttono, Fandi., 2002. Strategi Pemasaran edisi kedua, ANDI,Yogyakarta.

Undang-Undang Nomor 25 Tahun 1992 Tentang Perkoperasian

www.foragri.wordpress.com forum kerjasama Agribisnis, Produksi Ikan Gabus skala komersial. diakses tanggal 21 April 2015 